\title{
Optimizing the Performance of a Paper Mill Effluent Treatment
}

(Mengoptimumkan Prestasi Aliran Keluar Sisa Rawatan Kilang Kertas)

\author{
Moetaz ElSerganY*, Amimul AhSAn \& Md. ManiruZZaman A. AZIZ
}

\begin{abstract}
The paper making industry is characterized by high rate of water consumption and hence high rate of wastewater generation. The purpose of this research was to assess and optimize the existing complete mix activate sludge treatment plant that is used to treat the high strength paper mill effluent with the highest possible efficiency at a reasonable cost. The collected paper mill wastewater is equalized in an equalization tank before being pumped to the treatment plant. The treatment plant includes chemical treatment unit, complete mix activated sludge and granular media filtration unit. The results showed that effluent of a chemical treatment unit was found to be relatively similar to the laboratory simulated plain sedimentation unit. It can be concluded that addition of chemical coagulant can be eliminated with an overall saving of chemical addition costs. The complete mixing activated sludge achieved good removal of biochemical oxygen demand (BOD) and chemical oxygen demand (COD). Furthermore, the results showed that the plant is operated under low BOD:P ratio. The treatment efficiency of the plant can be improved by increasing the phosphorous dose to the plant to have BOD:P ratio of 100:0.5 to 100:1. It was found that 50\% of the treated effluent is recycled to the manufacturing process, however this percentage can be increased through proper plant optimization and control of nutrient addition to the activated sludge unit.
\end{abstract}

Keywords: Activated sludge; nutrient balance; paper mill effluent; paper recycling

\section{ABSTRAK}

Industri pembuatan kertas dicirikan oleh kadar penggunaan air yang tinggi dan dengan itu tinggi kadar penjanaan air kumbahan. Kajian ini bertujuan untuk menilai dan mengoptimumkan loji rawatan campuran lengkap enap cemar aktif yang digunakan untuk merawat aliran keluar kilang kertas berkualiti tinggi dengan kecekapan tertinggi pada harga yang berpatutan. Air sisa kilang kertas terkumpul dalam tangki penyamaan sebelum disalur ke loji rawatan. Loji rawatan adalah termasuk unit rawatan kimia, campuran lengkap enap cemar yang diaktifkan dan unit penapisan media butiran. Keputusan menunjukkan bahawa aliran keluar unit rawatan kimia didapati agak serupa dengan unit makmal simulasi pemendapan kosong. Dapat disimpulkan bahawa penambahan coagulant kimia boleh dihapuskan dengan penjimatan untuk keseluruhan kos tambahan kimia. Campuran lengkap enap cemar yang diaktifkan mencapai penyingkiran yang baik untuk permintaan oksigen biokimia (BOD) dan permintaan oksigen kimia (COD). Selain itu, hasil kajian menunjukkan bahawa loji dikendalikan di bawah nisbah BOD: P rendah. Kecekapan loji rawatan boleh diperbaiki dengan meningkatkan dos fosforus ke loji untuk nisbah BOD: P 100:0.5 ke 100:1. Didapati 50\% aliran keluar terawat yang dikitar semula dalam proses pembuatan, namun peratusan ini boleh ditingkatkan melalui pengoptimuman semula loji dan kawalan nutrien tambahan kepada unit enap cemar yang diaktifkan.

Kata kunci: Aliran keluar kilang kertas; diaktifkan enap cemar; kertas kitar semula; keseimbangan nutrien

\section{INTRODUCTION}

The expansion of industrialization and increased diversity of new products in the market have led to the increase in demand on different forms of packaging material. Plastic is extensively used as a source for packaging material because of its stability, durability, light weight, relatively low cost and flexibility to produce many forms for different purposes of packing process (Marsh \& Bugusu 2007). The use of plastic has begun to lose its popularity because of the environmental concerns related to its disposal despite of its wide spread as a packaging material. Paper and other packaging material started to gain popularity over plastic in some countries to minimize the environmental consequences of increased use of plastic. Market statistics about paper as packaging material indicate that paper has the largest share of global packaging market. For example in 2003 and 2009, paper and board represented about 39 and $38 \%$ of the overall global packaging market, respectively (WPO 2008).

Paper is an important and versatile material with a wide range of applications such as writing, printing and packaging purposes. Paper can be produced either from wood pulp as a primary source of fibers or from recycling waste paper as a secondary source of fibers (MacKinney 1995). The paper making industry is characterized by high rate of water consumption and hence high rate of 
waste water generation (Nemerow 2010). Recently, the fresh water consumption in the paper making process has markedly decreased due to the improvement in the manufacturing processes, the increased concern of the environmental sustainability, high cost of wastewater treatment and strict environmental standards related to waste disposal. Today's trend is towards more wastewater circulation systems in the paper manufacturing (Lens et al. 2002) with the ultimate goal to have a closed loop water circulation system. Recycling of water within the industry can reduce the stress on the fresh water consumption and reduce the company's environmental liabilities related to waste disposal standards (Blanco et al. 2004).

In the paper making process, the amount of generated wastewater depends on the water conservation practice applied to the paper making process. The characteristics of the generated waste are mainly affected by the degree of contamination and characteristics of raw material, percentage of virgin pulp used in paper making, the chemicals used for pulp preparation, degree of water conservation and percentage of wastewater recycling (Miranda et al. 2009; Monte et al. 2009).

The industrial wastewater generated by the paper making process can be treated by a combination of physical, chemical and biological processes (Möbius 2006). The physical treatment process includes either sedimentation or floatation. The sedimentation process is much preferred over the floatation which give a high percentage of suspended solids removal. Sedimentation process can remove up to $80 \%$ of the suspended solids in the paper mill wastewater (Saunamaki 1997). Chemicals may be added like alum or polymer to enhance the sedimentation process. Soluble organic matter expressed as BOD or COD are removed by biological treatment using aerobic suspended growth pattern such as activated sludge and its modifications. In the activated sludge process, nutrients such as phosphorous and nitrogen are needed to achieve the desired level of treatment. Nutrients are added to attain the $\mathrm{BOD}_{5}: \mathrm{N}: \mathrm{P}$ ratio near 100:5:1 (Möbius 2006).

On the other hand, anaerobic treatment can be used to treat the paper mill effluent where this is applicable in cases of high organic loads. In fact, the anaerobic treatment is not widely used as the activated sludge process. The anaerobic treatment has many advantages over the activated sludge such as methane gas production, small land requirements and reduced sludge production (Pokhrel \& Viraraghavan 2004). The reason of preferring the aerobic process over the anaerobic process may be due to the temperature requirement, sensitivity of the process and relatively slow growth rate of the methanogenic bacteria in the anaerobic process (Rintala \& Puhakka 1994; Tchobanoglous et al. 2003). The effluent from biological treatment can be tertiary treated for further removal of color and suspended solid to render the effluent suitable either for disposal or recycling into the process. Tertiary treatment includes different modifications and can include one or more of the following techniques such as filtration, adsorption, coagulation and ozonation (Thompson et al. 2001). The selection of the appropriate tertiary treatment is governed by many factors such as disposal standards, receiving environment and the intended use of the treated effluent.

In this study, an industrial wastewater treatment plant treating paper mill wastewater was selected in the industrial city, Eastern Province, Kingdom of Saudi Arabia. The paper mill produces packaging paper with an average daily capacity of 550 metric tons per day. The total amount of generated wastewater is about $2500 \mathrm{~m}^{3} / \mathrm{d}$

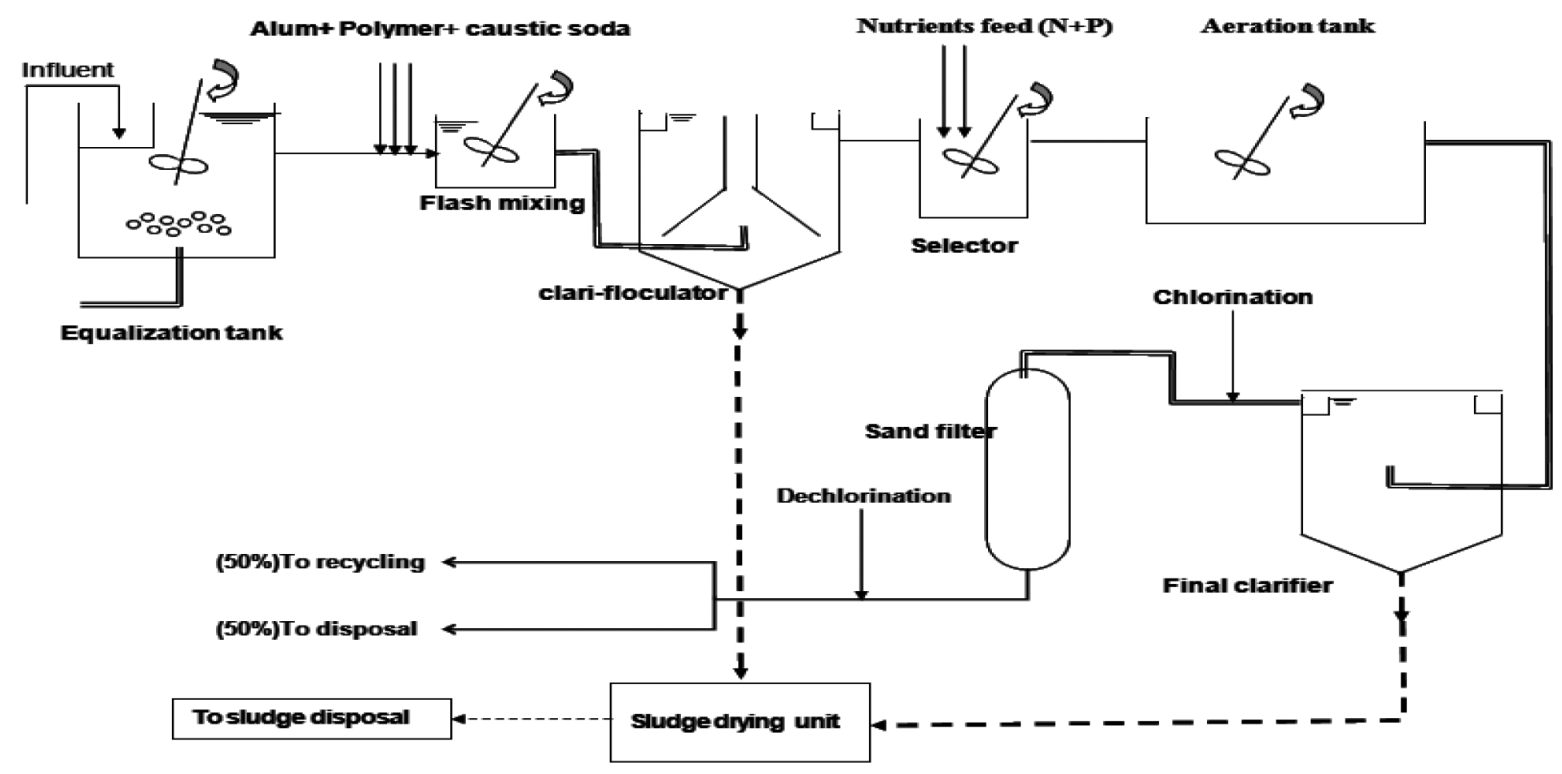

FIGURE 1. Flow diagram of paper mill effluent treatment plant 
which corresponds to an average of $4.5 \mathrm{~L} / \mathrm{kg}$ of product. The waste influent is treated by a sequence of physical, chemical and biological treatment. As shown in Figure 1 , the waste influent is equalized in an equalization basin $\left(880 \mathrm{~m}^{3}\right)$ to maintain a constant flow of waste to the treatment unit and to dampen any unexpected fluctuation in the waste characteristics. The equalized waste influent is chemically treated using alum and polymer as a coagulant to enhance the settling of fine suspended solids. The chemical treatment unit includes a flash mixing basing $\left(3.5 \mathrm{~m}^{3}\right)$ followed by a clariflocculater unit (222 $\mathrm{m}^{3}$ ) in which both flocculation and sedimentation occur simultaneously. The chemically treated effluent is treated by a complete mix activated sludge process. Nitrogen and phosphorous are added before the biological treatment to ensure proper performance and stability of the process. Furthermore, selector basins are added prior the activated sludge to limit the growth of filamentous bacteria and improve settling characteristics of the activated sludge. The secondary treated effluent is further treated using sand filters as final tertiary treatment stage. Currently, a portion of the treated effluent is recycled to the industrial process to minimize the water consumption and the remaining portion is disposed to another central industrial central treatment plant treating industrial wastes from different industrial sources in the city. The generated sludge from the primary and secondary treatment processes are mechanically dried after being treated by addition of polymer. The dry sludge is sent to the landfill outside the plant.

This study aimed to assess and optimize existing complete mix activate sludge to treat the high strength paper mill effluent with the highest possible efficiency at reasonable cost.

\section{MATERIALS AND METHODS}

Weekly samples were collected from raw wastewater influent after equalization, the effluent of chemical treatment unit, effluent of activated sludge unit, final effluent and from the aeration tank for a period of 2 months. The samples were collected, preserved and analyzed for physicochemical parameters according to Standard Methods for the Examination of Water and Wastewater (Eaton \& Franson 2005).

To assess the efficiency of the chemical treatment unit, the raw wastewater samples were divided into two portions. The first portion was analyzed to determine the influent wastewater characteristics and the second portion (one liter) was allowed to settle for $1 \mathrm{~h}$ in Imhoff cone hence the supernatant was taken for physicochemical analysis to assess the use of plain sedimentation as an alternative for chemical treatment process. The final effluent characteristics were compared with the local environmental law to determine the compliance of the treated effluents with the Kingdom of Saudi Arabia discharges permits (General Environmental Law and its executive order for Kingdom of Saudi Arabia 2001).

\section{RESULTS AND DISCUSSION}

\section{CHEMICAL TREATMENT UNIT}

Table 1 depicts the raw wastewater influent characteristics compared with the chemical treatment unit and the laboratory plain sedimentation experiment results. $\mathrm{pH}$ values ranged from 5.6 to 5.8 and 6.1 to 6.4 for the equalized raw wastewater influent and the chemical treatment unit effluent, respectively. Apparently, the $\mathrm{pH}$ value showed an increase in the chemical treatment effluent as a result of addition of caustic soda which is added to overcome the alkalinity reduction due to alum addition. The average percentage removals of turbidity, COD, BOD and suspended solids (SS) by the chemical treatment unit were 64, 22, 21 and 68, respectively. On the other hand, the average percentage removals of the same parameters by the laboratory plain sedimentation unit were 59, 31, 24 and 58, respectively. Comparison of the characteristics of the chemical treatment unit effluent with the results of the plain sedimentation without chemical addition showed that there may be slight improvement in case of chemical addition, accordingly the alum and polymer addition could be eliminated and the unit can be converted to plain sedimentation tank without any chemical addition. It can be said that the elimination of chemical addition can outweigh the advantages of the insignificant improvements in effluent quality. The average daily consumption of alum and polymer was found to be 700 and $40 \mathrm{~kg} / \mathrm{d}$, respectively, eliminating the use of these chemicals to reduce the annual cost of chemicals by about $69000 \$$ for alum and about $60000 \$$ for polymer based on an estimated cost of 270 $\$$ per ton of alum and $4200 \$$ per ton of polymer. The resulting primary sludge mainly contains fibers washed out of the paper making process; accordingly eliminating the use of chemicals to increase the chance of reusing this settled sludge in the paper making process which can lead to additional advantage of reducing the cost of sludge handling process. In fact this suggested option is still under investigation by the plant operators to assess the effect of reusing these settled fibers on the product quality, furthermore, the plant operators are investigating another alternative which is separating these fibers before being pumped to the industrial wastewater treatment unit. The expected daily amount of sludge reduction in case of reusing the settled fibers will be about $87 \mathrm{~m}^{3} / \mathrm{d}$ based on average settleable solids of $35 \mathrm{~mL} / \mathrm{L}$ and a daily wastewater flow of $2500 \mathrm{~m}^{3} / \mathrm{d}$.

\section{ACTIVATED SLUDGE UNIT}

As shown in Table 2, the complete mix activated sludge reactor was operated at an average influent BOD and COD of 4190 and $7387 \mathrm{mg} / \mathrm{L}$, respectively. Apparently the aeration tank is operated at high influent organic loading conditions. The high effluent BOD and COD necessitate the operation of the tank at high level of mixed liquor suspended solids to maintain food microorganism's ratio $(\mathrm{F} / \mathrm{M})$ at the desired level. The $\mathrm{F} / \mathrm{M}$ ratio in the selector 
TABLE 1. Mean value of raw wastewater influent, chemical treatment unit effluent and laboratory plain sedimentation results

\begin{tabular}{lcccccc}
\hline \multirow{2}{*}{ Parameter } & \multirow{2}{*}{ Unit } & \multicolumn{2}{c}{ Raw } & \multicolumn{2}{c}{ Chemical treatment unit } & \multicolumn{2}{c}{ Plain sedimentation } \\
\cline { 3 - 7 } & & influent & Effluent & \%Rem. & Effluent & \%Rem. \\
\hline $\mathrm{pH}$ & --- & $5.6-5.8$ & $6.1-6.4$ & -- & $5.6-5.8$ & -- \\
Turbidity & $\mathrm{NTU}$ & 454 & 165 & 64 & 187 & 59 \\
Chlorides & $\mathrm{mg} / \mathrm{L}$ & 555 & 534 & 4 & 537 & 3 \\
Total alkalinity & $\mathrm{mg} \mathrm{CaCO}_{3} / \mathrm{L}$ & 185 & 130 & 30 & 185 & --- \\
Chemical oxygen demand & $\mathrm{mg} / \mathrm{L}$ & 9507 & 7387 & 22 & 6590 & 31 \\
Biochemical Oxygen Demand & $\mathrm{mg} / \mathrm{L}$ & 5279 & 4190 & 21 & 4036 & 24 \\
Suspended Solids & $\mathrm{mg} / \mathrm{L}$ & 1747 & 560 & 68 & 737.5 & 58 \\
Settleable solids after30 min & $\mathrm{mL} / \mathrm{L}$ & 35 & 0.3 & 99 & $\mathrm{NA}$ & $\mathrm{NA}$ \\
Total Phosphorous & $\mathrm{mg} / \mathrm{L}$ & 0.83 & 0.9 & --- & 0.83 & --- \\
Total Nitrogen & $\mathrm{mg} / \mathrm{L}$ & 2.1 & 2.4 & --- & 2.1 & -- \\
\hline
\end{tabular}

TABLE 2. mix aeration tank operational characteristics treating paper recycling wastewater

\begin{tabular}{|c|c|c|c|}
\hline Parameter & Unit & Range & Average \\
\hline $\mathrm{pH}$ & ---- & $6.7-6.9$ & ---- \\
\hline DO & $\mathrm{mg} / \mathrm{L}$ & $2-3$ & 2.80 \\
\hline influent BOD & $\mathrm{mg} / \mathrm{L}$ & $3970-4600$ & 4190 \\
\hline Influent COD & $\mathrm{mg} / \mathrm{L}$ & $6891-7999$ & 7387 \\
\hline Influent Total N & $\mathrm{mg} / \mathrm{L}$ & $1.85-3.16$ & 2.40 \\
\hline Influent Total P & $\mathrm{mg} / \mathrm{L}$ & $0.6-0.95$ & 0.90 \\
\hline S.S & $\mathrm{mg} / \mathrm{L}$ & 4227 & $3642-4600$ \\
\hline $\mathrm{F} / \mathrm{M}$ ratio $(\mathrm{S})^{*}$ & $\mathrm{Kg}$ BOD/Kg MLSS.d & 5 & $5.5-4.5$ \\
\hline $\mathrm{F} / \mathrm{M} \operatorname{ratio}(\mathrm{A}) * *$ & Kg BOD/Kg MLSS.d & 0.04 & $0.037-0.046$ \\
\hline BOD loading to selector & $\mathrm{Kg} / \mathrm{d}$ & $9925-11500$ & 10475 \\
\hline BOD loading to aeration tank & $\mathrm{Kg} / \mathrm{d}$ & 7940-9200 & 8380 \\
\hline vol. loadig & $\mathrm{Kg} \mathrm{BOD} / \mathrm{m}^{3} \cdot \mathrm{d}$ & $0.5-0.6$ & 0.55 \\
\hline Set. Sol(30) & $\mathrm{mL} / \mathrm{L}$ & $540-670$ & 603 \\
\hline SVI & $\mathrm{mL} / \mathrm{g}$ & 119 & 108-142 \\
\hline BOD:N:P ratio ${ }^{(* * *)}$ & NA & ----- & 100:.057:.022 \\
\hline amount of nitrogen added & $\mathrm{Kg} / \mathrm{d}$ & ----- & 438 \\
\hline amount of $\mathrm{P}$ added & $\mathrm{Kg} / \mathrm{d}$ & & 24 \\
\hline BOD:N:Pratio after nutrient addition $(*)$ & NA & & $100: 4.2: 0.25$ \\
\hline
\end{tabular}

(*) Selector basin.

(**) Aeration tank.

(***) Calculations of BOD:N:P were done on the average values.

basin ranged from 4.5 to 5.5 with an average value of $5 \mathrm{~kg}$ $\mathrm{BOD} / \mathrm{kg}$ MLSS.d. In activated sludge systems the selector is used to control the formation of filamentous bacteria in the complete mix aeration tanks which can create a high $\mathrm{F} / \mathrm{M}$ ratio gradient between the selector and the aeration tank; the condition that can discourage the proliferation of filamentous bacteria and encourage (Thompson et al. 2001). The results obtained in this study showed that the incorporation of the selector before the complete mix activated sludge aeration tank improved the settling characteristics of the generated activated sludge. Sludge settling characteristics were assessed using the sludge volume index (SVI) which ranged from 108 to $140 \mathrm{~mL} / \mathrm{L}$ with an average value of $119 \mathrm{~mL} / \mathrm{L}$.

With respect to nutrient balance, the incoming influent showed a significant deficiency in nitrogen and phosphorous. The BOD: N: P ratio was 100:0.057:0.022. The optimum recommended ratio is 100:5:1 (Ammary 2004; Tchobanoglous et al. 2003). It was found that the nutrient deficiency is compensated by daily addition of $1400 \mathrm{~kg}$ of $38 \%$ ammonia solution and $250 \mathrm{~kg}$ of $30 \%$ phosphoric acid solution. The final BOD: N: P ratio was 100:4.2:0.25. This ratio is considered satisfactory with regards to nitrogen and low with regards to phosphorous. Accordingly it would be recommended to increase the daily addition of phosphorus to increase the BOD: N: $\mathrm{P}$ ratio to the recommended levels which can results in improved COD and BOD removal efficiency. A recent study (Slade et al. 2011) on investigating effect of BOD:N:P ratio showed that $\mathrm{N}$ levels do not affect the organic carbon removal but strongly influence the floc structure because of the growth of filamentous bacteria. BOD:N:P ratio in activated sludge 
treating paper and mill wastes can range from 100:4:0.8 to $100: 3: 0.5$ without imposing a negative impact on the organic matter degradation or bacterial growth in the activated sludge process (Möbius 2006). It is reported that sever phosphorous deficiencies can interfere with the formation of the activated sludge, however moderate or suboptimal concentration of phosphorous can lead to retardation of biomass growth and reduced BOD removal (Greenberg et al. 1955). Accordingly, increasing the added amount of phosphorous to $500 \mathrm{~kg}$ /day of $30 \%$ phosphoric acid can lead to additional improvement in the plant performance. Increasing phosphorous dose to the activated sludge influent can lead to many improvements in the final treated effluent such as reduction in secondary effluent BOD and total nitrogen. As shown in Table 3, the percentage removals of COD, BOD and SS of activated sludge process were 87,93 and $46 \%$. With respect to total nitrogen there was an increase in the treated effluent compared to the influent. This can be due to incomplete consumption of nitrogen due to phosphorous deficiency in the activated sludge tank (Greenberg et al. 1955). The increase of phosphorous dose to activated sludge may result in direct improvements in the operation of activated sludge process. This may include the reduction of the return activated sludge which can lead to reduction in the overall pumping and aeration costs. It is reported that at low sludge age the nutrient requirements for activated sludge increase and the aeration costs decrease, however the activated sludge tank can be operated at the minimum dose of nutrient by increasing the sludge age which can lead to significant increase in the aeration costs (Lindblom et al. 2004). Selecting the appropriate aeration mode of operation at low phosphorous level and long sludge age (more return activated sludge) or operation at optimum phosphorous level and short sludge age (less return activated sludge) is subject of weighing the overall benefits versus the net cost. This suggestion has been conveyed to plant operators where the best operation mode will be studied in the future.

\section{TERTIARY TREATMENT UNIT}

The final effluent characteristics of the wastewater treatment plant treating the paper recycling wastewater is presented in Table 4 . The tertiary treatment is composed of sand filters where waste is chlorinated before filtration to prevent any unwanted biological growth inside filters. After the filtration process, the effluent is dechlorinated and about $50 \%$ of the waste is recycled to the production line and the remaining $50 \%$ is disposed to the main wastewater treatment plant. Filtration process removed about $63 \%$ of the suspended solids where the final effluent SS decreased from $300 \mathrm{mg} / \mathrm{L}$ in secondary treated effluent to $110 \mathrm{mg} / \mathrm{L}$ in the filtered effluent. Apparently the tertiary treatment unit showed limited removal efficiency of BOD and COD where the majority of remaining BOD and COD exist in soluble form. More percentage of effluent reuse could be expected after elimination of chemical use in primary treatment unit and increasing phosphorous dose to the activated sludge. The elimination of chemical use in primary treatment unit can reduce the total dissolved solids in the treated effluent while adjustment of phosphorous addition can lead to increase efficiency of BOD and COD removals which can in turn improve the effluent quality towards more reuse.

\section{CONCLUSION AND RECOMMENDATIONS}

The results of this study showed that effluent contains considerable amount of fibers which can be collected and recycled to the paper mill. Furthermore the study showed that using plain sedimentation can give comparable

TABLE 3. Clarified activated sludge effluent compared to chemical treatment unit effluent

\begin{tabular}{lccc}
\hline Parameter & $\begin{array}{c}\text { Chemical treatment unit } \\
\text { effluent }\end{array}$ & $\begin{array}{c}\text { Secondary treatment unit } \\
\text { effluent }\end{array}$ & \% removal \\
\hline pH & $6.1-6.4$ & $7.1-7.2$ & ----- \\
COD (mg/L) & 7387 & 977 & 87 \\
BOD (mg/L) & 4190 & 290 & 93 \\
SS (mg/L) & 560 & 300 & 46 \\
Total phosphorous (mg/L) & 0.9 & 0.32 & 64 \\
Total nitrogen (mg/L) & 2.4 & 6.3 & -- \\
\hline
\end{tabular}

TABLE 4. Characterization of tertiary treatment unit effluent

\begin{tabular}{lcc}
\hline Parameter & Tertiary treatment unit effluent & Percentage removal \\
\hline $\mathrm{pH}$ & $7.2-7.5$ & ---- \\
$\mathrm{COD}(\mathrm{mg} / \mathrm{L})$ & 750 & 23 \\
$\mathrm{BOD}(\mathrm{mg} / \mathrm{L})$ & 233 & 20 \\
$\mathrm{SS}(\mathrm{mg} / \mathrm{L})$ & 110 & 63 \\
Total phosphorous $(\mathrm{mg} / \mathrm{L})$ & 0.31 & --- \\
Total nitrogen $(\mathrm{mg} / \mathrm{L})$ & 6.5 & ---- \\
\hline
\end{tabular}


efficiencies when compared to chemical addition while eliminating the cost of chemical coagulants as well as the processing costs of treating chemical sludge. It can be concluded that the presence of paper fibers in the manufacturing effluent could be eliminated either by proper in-plant control or by recycling this settled fibers. The process of recycling settled fibers needs further assessment to assess the impact of recycling these fibers on the quality of the final product. In this study the biological unit was operated under low BOD:P ratio while producing a relatively good effluent quality with a BOD and COD removal efficiencies of 87 and $93 \%$, respectively. It is expected the biological unit operation performance could be improved by increasing the BOD:P ratio to level of 100:0.5 to 100:1, however an additional study must be conducted to investigate the effect of the proposed increase in the chemical phosphorous dose to the activated sludge tank with respect to the overall improvements versus the possible additional costs of chemical phosphorous addition.

\section{REFERENCES}

Ammary Bashaar, Y. 2004. Nutrients requirements in biological industrial wastewater treatment. African Journal of Biotechnology 3(4): 236-238.

Blanco, A., Negro, C., Monte, C., Fuente, E. \& Tijero, J. 2004. Peer reviewed: The challenges of sustainable papermaking. Environmental Science \& Technology 38(21): 414A-420A.

Eaton, A.D. \& Franson, M.A.H. 2005. Standard Methods for the Examination of Water \& Wastewater. 21st ed. Washington DC, USA: Amer Public Health Association.

General Environmental Law and its executive order for Kingdom of Saudi Arabia. 2013. Presidency of Meteorology and Environment 2001. http://www.pme.gov.sa/EnvARules. pdf. Accessed on January 2013.

Greenberg, A.E., Klein, G. \& Kaufman, W.J. 1955. Effect of phosphorus on the activated sludge process. Sewage and Industrial Wastes 27(3): 277-282.

Lens, P., Hulshoff Pol, L., Wilderer, P. \& Asano, T. 2002. Water Recycling and Resource Recovery in Industry: Analysis, Technologies and Implementation. London: IWA Publishing.

Lindblom, E., Rosen, C., Vanrolleghem, P.A., Olsson, L.E. \& Jeppsson, U. 2004. Modelling a nutrient deficient wastewater treatment process. Paper read at Fourth IWA World Water Conference, Marrakech, Morocco.

MacKinney, R.W.J. 1995. Technology of Paper Recycling. New Jersey: Blackie Academic and Professional.

Marsh, K. \& Bugusu, B. 2007. Food packaging - roles, materials, and environmental issues. Journal of Food Science 72(3): R39-R55.

Miranda, R., Blanco, A. \& Negro, C. 2009. Accumulation of dissolved and colloidal material in papermaking - Application to simulation. Chemical Engineering Journal 148(2-3): 385-393.

Möbius, C.H. 2006. Water Use and Wastewater Treatment in Papermills: Books on Demand.

Monte, M.C., Fuente, E., Blanco, A. \& Negro, C. 2009. Waste management from pulp and paper production in the European Union. Waste Management 29(1): 293-308.
Nemerow, N.L. 2010. Industrial Waste Treatment: Contemporary Practice and Vision for the Future. Burlington: ButterworthHeinemann.

Pokhrel, D. \& Viraraghavan, T. 2004. Treatment of pulp and paper mill wastewater-a review. The Science of the Total Environment 333(1-3): 37.

Rintala, J.A. \& Puhakka, J.A. 1994. Anaerobic treatment in pulpand paper-mill waste management: A review. Bioresource Technology 47(1): 1-18.

Saunamaki, R. 1997. Activated sludge plants in Finland. Water Science and Technology 35(2-3): 235-243.

Slade, A., Thorn, G. \& Dennis, M. 2011. The relationship between BOD: $\mathrm{N}$ ratio and wastewater treatability in a nitrogen-fixing wastewater treatment system. Water Science \& Technology 63(4): 627-632.

Tchobanoglous, G., Burton, F. \& Stensel, H.D. 2003. Wastewater Engineering: Treatment and Reuse. New York: Metcalf and Eddy, McGraw-Hill.

Thompson, G., Swain, J., Kay, M. \& Forster, C.F. 2001 The treatment of pulp and paper mill effluent: A review. Bioresource Technology 77(3): 275-286.

WPO. 2008. Market statistics and future trends in global packaging. World packaging organisation. http://www. worldpackaging.org/uploads/paperpublished/2_pdf. Accessed on 21 April 2013.

Moetaz ElSergany*

School of Health \& Environmental Studies

Hamdan Bin Mohammed Smart University

Dubai, United Arab Emirates

Amimul Ahsan

Department of Civil Engineering and Institute of Advanced Technology

Universiti Putra Malaysia

43400 Serdang, Selangor Darul Ehsan

Malaysia

Md. Maniruzzaman A. Aziz

Faculty of Civil Engineering

Universiti Teknologi Malaysia (UTM)

81310 Skudai, Johor Darul Takzim

Malaysia

Md. Maniruzzaman A. Aziz

UTM Construction Research Center (CRC)

Universiti Teknologi Malaysia (UTM)

81310 Skudai, Johor Darul Takzim

Malaysia

*Corresponding author; email: m.elsergany@hbmsu.ac.ae

Received: 29 May 2014

Accepted: 7 July 2014 